\title{
Prevalence of Mastitis in Lactating Bovines and Associated Coliforms Among Selected Pastoral Herds in Parts of Kaduna State, Nigeria
}

\author{
D. Makolo* \\ Department of Microbiology, Faculty of Life Sciences, Ahmadu Bello University, Zaria, Nigeria \\ Department of Sciences, School of Preliminary Studies, Kogi State Polytechnic, Lokoja \\ A. B. Suleiman \\ Department of Microbiology, Faculty of Life Sciences, Ahmadu Bello University, Zaria-Nigeria

\section{O. S. Olonitola} \\ Department of Microbiology, Faculty of Life Sciences, Ahmadu Bello University, Zaria-Nigeria
}

\author{
M. Bello
}

Department of Veterinary Public Health and Preventive Medicine, Faculty of Veterinary Medicine, Ahmadu Bello University, Zaria, Nigeria

\section{Ahmadu}

Department of Microbiology, Faculty of Life Sciences, Ahmadu Bello University, Zaria-Nigeria

\section{F. O. Awulu}

Department of Microbiology, Faculty of Life Sciences, Ahmadu Bello University, Zaria-Nigeria

\author{
Y. Aliyu
}

Department of Science Laboratory Technology, Federal Polytechnic, Nasarawa-Nigeria

\section{Hammuel}

Department of Microbiology, Faculty of Life Sciences, Ahmadu Bello University, Zaria-Nigeria

\author{
R. P. Enenya
}

Department of Microbiology, Faculty of Life Sciences, Ahmadu Bello University, Zaria-Nigeria

\author{
M. P. Itua
}

Department of Science, School of Preliminary Studies, Kogi State Polytechnic, Lokoja- Nigeria

\begin{abstract}
It has been established by various researchers that bovine mastitis which is simply an inflammation of mammary gland is a complex and costly disease in dairy herds globally. This study therefore was aimed at assessing the prevalence of clinical and subclinical mastitis among lactating bovines from pastoral herds. A total of 147 bovines were selected from 30 pastoral herds within 7 Fulani settlements in Kaduna State, Nigeria. Prevalence of Clinical mastitis was assessed by the result of physical examination of udders and milk by palpation and visual inspection. The California Mastitis Reagent was used according to the manufacturer's instructions to detect the prevalence of Subclinical Mastitis. The CMT positive samples were bacteriologically analyzed following standard microbiological procedures for the presence of coliform bacteria. The results obtained revealed that 19.7\% (29/147) of animals examined was positive for subclinical mastitis at cow level. The highest prevalence of subclinical mastitis was recorded among bovines from settlements G in Birnin Gwari Local Government Area of Kaduna State, while bovine's raw milk samples collected from settlements $\mathrm{C}$ and $\mathrm{E}$ in Chikun and Zaria Local Government Areas of Kaduna State haboured the lowest number of $1(0.7 \%)$ each, and no Coliform bacteria $(0.00 \%)$ was isolated in the samples collected from settlement D in Soba Local Government Area. In this study, a total prevalence of $8.2 \%$ was established for coliforms associated with subclinical mastitis among pastoral herds based on phenotypic identification. Furthermore, the species of coliforms associated with bovine mastitis within the study population based on the findings in this study were (Klebsiella pneumonia) 7(4.8\%) and (Escherichia coli) 5(3.4\%). Hence, this study confirmed that the consumption of raw milk from CMT positive commercial bovines is a potential threat to public health as the isolated species of coliforms have been implicated in several human diseases.
\end{abstract}

Keywords: Bovines; Pastoral herds; Klebsiella pneumonia; Escherichia coli; Subclinical mastitis. 


\section{Introduction}

In Nigeria, livestock represents an integral part of the agricultural system, especially in the northern part of the country [1]. Among all the livestock that makes up the farm animals in Nigeria, ruminants comprising of sheep, goat, and cattle, constitutes the farm animals largely reared [1]. Nigeria has a population of about 13.9 million cattle, 34.5 million goats, 22.1 million sheep [1]. Therefore, according to Shittu, et al. [2], it is of great economic importance to improve on livestock production which is one of the ample national resources in Nigeria.

However, the potential for increasing livestock production in Nigeria can only be fully realized if the animals are adequately protected against the adverse effects of diseases such as mastitis [2]. According to Sumathi [3], profitability of animal products demands efficient husbandry of animals, as disease remains one of the major threats to optimal livestock production. Hence, integrated approach to mastitis control is required in order to meet the ever growing human population and the economic crisis in Nigeria.

Mastitis is the inflammation of mammary gland and is a complex and costly disease in dairy herds [4,5]. According to Radostis, et al. [6] and Sharma, et al. [7], mastitis is characterized by means of chemical, bodily, and bacteriological changes inside the milk, and pathological adjustments within the glandular tissue of the udder. Gera and Guha [8] reported that the occurrence of disease is a product of interaction between three factors: infectious agents, environmental and host resistance factors.

Mastitis is a global problem as it adversely affects animal health, quality of milk and the economics of milk production. It affects every country, including developed ones and causes huge financial losses [9]. There is agreement among authors that mastitis is the most widespread infectious diseases in dairy cattle, and, from an economic aspect, the most damaging [2, 10-14].

The term Coliform bovine mastitis is frequently used incorrectly to identify mammary disease caused by all Gram-negative bacteria, but the Genera classified as Coliform are Escherichia, Klebsiella and Enterobacter [15]. Specifically, Escherichia coli and Klebsiella pneumonia are the Coliform species most commonly isolated from intramammary infections and cases of clinical mastitis [15]. In some countries, the prevalence of Coliform mastitis is increasing and the control of Coliform mastitis is a critical issue due to emergence of multiple drug resistant coliforms [3].

Furthermore, Coliform bacteria occupy many habitats in the bovine's environment, and may be isolated from virtually any surface area of the bovines or their surroundings. But, the point source of Coliform that cause mastitis include bedding materials, soils, manure and other organic matter in bovines environment [15]. Therefore, poor hygienic standard of rearing and milking may exposed the animals to cases of Coliform mastitis [13]. Therefore, this present study is aimed at assessing the prevalence of mastitis among pastoral herds and associated coliforms in Parts of Kaduna State, Nigeria.

\section{Methodology}

\subsection{Study Area}

This study was carried out among the pastoral herds in Kaduna State, Nigeria which is located in the Northwest Geopolitical Zone of Nigeria. It lies between latitude $6^{\circ}$ and $11^{\circ}$ North and longitude $7^{\circ}$ and $44^{\circ}$ East and is $608 \mathrm{~m}$ above sea level. It has distinct wet and dry seasons within the Guinea Savannah and part of the Sudan Savannah in Nigeria. Kaduna State is made up of 23 Local Government Areas (LGAs) and occupying about 48,473.25 square kilometers [16]. According to Ugwu [17], the estimated number of cattle in Kaduna State is 2,041,049, while the number of bovines-in-milking is 771,516. Total milk production per anum is 416.7 million litres with a yield figure of 1.5 litres per day and the estimated income per animal per day is about N250.00. Kaduna State is endowed with a number of livestock breeds such as cattle (Bunaji), goats (Sokoto red, West African Dwarf), sheep (Yankari, Balami, Uda), pigs (Yorkshire, Hamphshire), poultry (Layers, Broilers, Ducks, Turkeys, etc), rabbits, fish and bees-hives [17].

Agriculture is the main stay of the economy of Kaduna State with about $80 \%$ of the people actively engaged in farming. Another major occupation of the people is animal rearing and poultry farming. The animals reared include cattle, sheep, goats and pigs [16]. Pastoralism, Pastoralism, Agropastoralism and intensive dairy farming are the predominant dairy production systems in Kaduna State. The pastoralists move around with their herds in search of fresh pasture land or grazing areas. Agropastoralism is practiced by farmers who grow food crops and keep livestock, while the intensive dairy farmers use part or all of their land to grow fodder crops for their dairy cattle [17].

\subsection{Study Population}

The study population constitutes the lactating bovines of the Nigerian indigenous breeds. The animals were selected from the pastoral herds in some herdsmen settlements in parts of Kaduna State, Nigeria.

\subsection{Study Design}

A cross-sectional study was carried out on seven herdsmen settlements comprising of thirty herds of bovines across Kaduna State, Nigeria. The settlements were selected using a purposive sampling technique. The selection was based on the availability of lactating bovines that are not currently on treatment, willingness of the farmers/pastoralists to participate in the study, and accessibility of the location in order to easily transport samples 
collected to the laboratory for further analysis. Seven Local Government Areas (Chikun, Igabi, Soba, Birnigwari, Sabongari, Zaria and Giwa) were studied based on the available information at the National Commission for Nomadic Education, Kaduna State. One herdsmen settlement was purposively selected from each Local Government Area studied. To preserve anonymity, the studied settlements were assigned reference letters.

\section{Physical Examination of the Udder and Milk}

The udders were first examined visually and then palpated to detect any possible fibrosis, inflammatory swelling and atrophy of the tissues. The size and consistency of the mammary quarters were inspected for the presence of any abnormalities such as disproportional symmetry, swellings, firmness and blindness of the teat canal. In addition, milk collected from the quarters were visually inspected for presence of any flakes, clots, pus, watery appearance, blood and colour change [18-20].

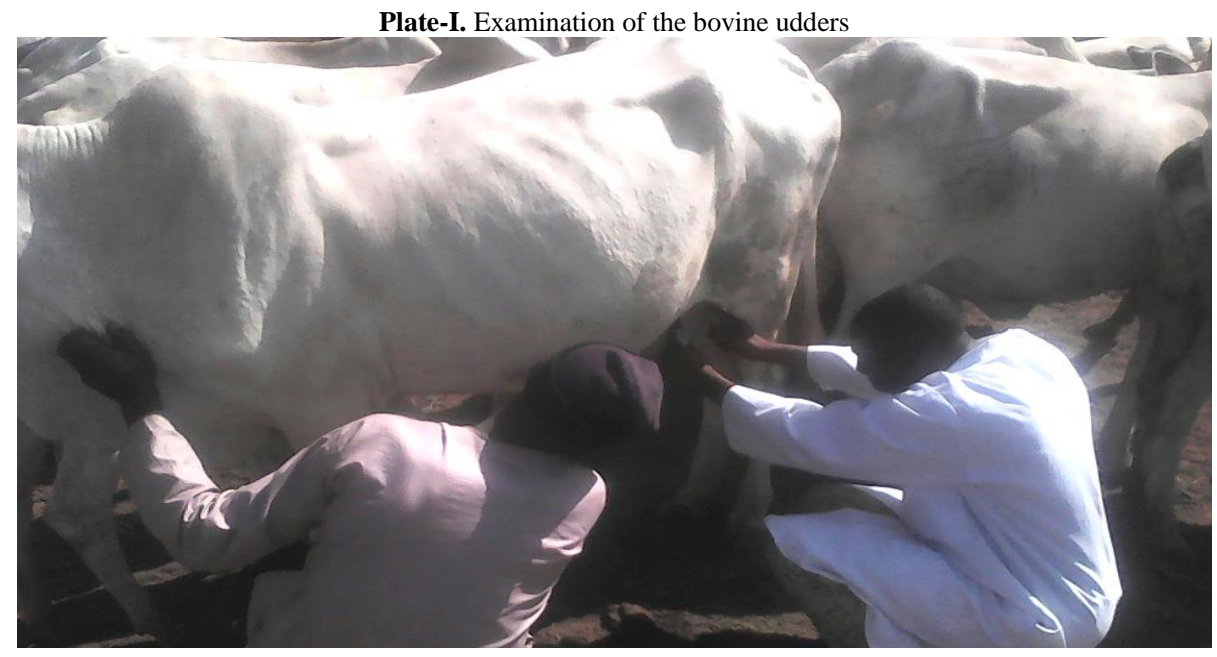

\section{Sample Collection}

Strict aseptic procedures was followed to prevent contamination with microorganisms present on the skin of udder and teats, hands of samplers and barn environment according to the methods of National Mastitis Council Guidelines described by Middleton, et al. [21]. Briefly, prior to milk sample collection, udders and teats were cleaned using a disposable paper towel immersed in $70 \%$ ethyl alcohol and dried to avoid presence of feacal debris in the milk as it could obstruct the accurate interpretation of CMT result. Foremilk (first jets) was discharged to reduce the contamination of teat canal. Sterile universal bottles with tight fitting cups were used. The bottles were labeled appropriately with permanent marker before sampling. However, in order to reduce contamination of teat ends during sample collection, the near teats were sampled first and then followed by the far ones. About $8 \mathrm{mls}$ of raw milk was aseptically collected from each bovine ( $2 \mathrm{mls}$ from each quarter). The samples were properly labeled and CMT positive samples were immediately transported to the Department of Microbiology, Faculty of Life Science, Ahmadu Bello University, Zaria in an ice box for bacteriological analysis.

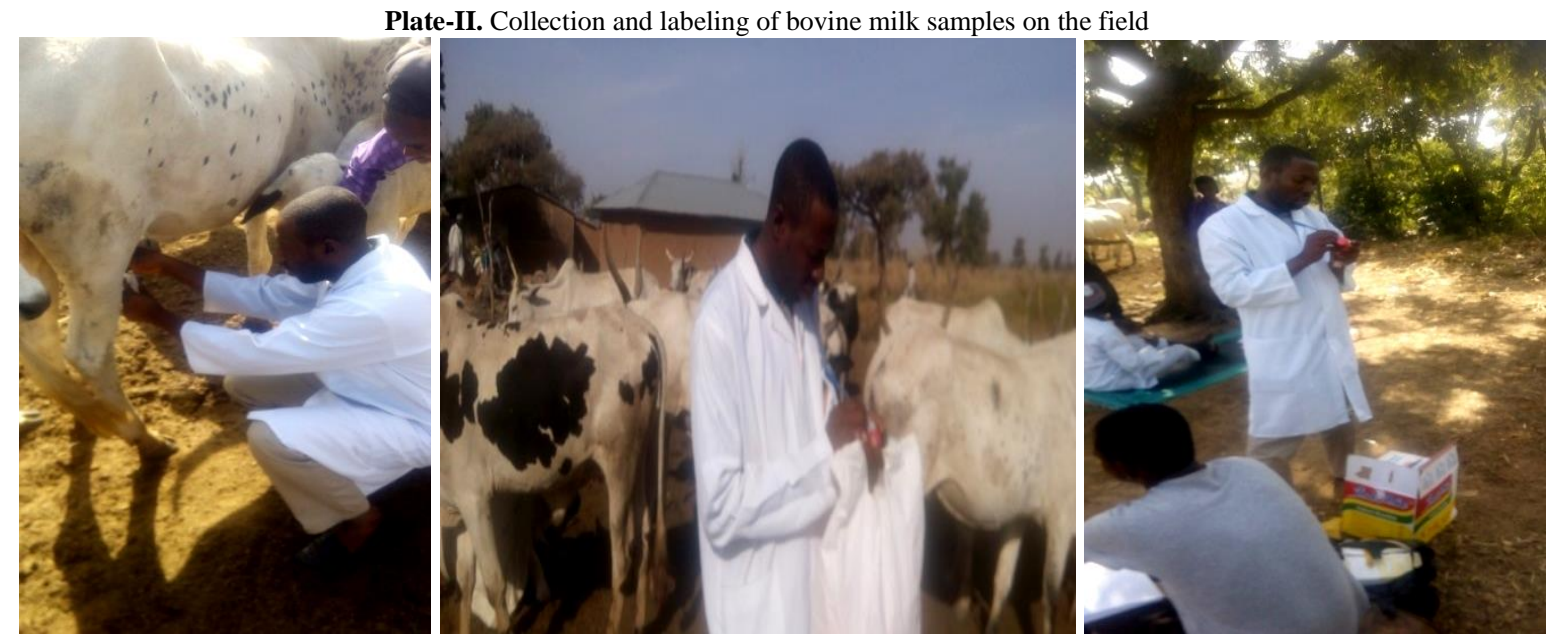

\section{Detection of Subclinical Mastitis}

The California Mastitis Reagent was used according to the manufacturer's instructions as shown in Plate V. Briefly; $2 \mathrm{mls}$ of milk samples was collected directly from each quarter of the udder and mixed together. $2 \mathrm{mls}$ of the 
composite milk sample was then added to $2 \mathrm{mls}$ of CMT reagent on the test paddle and mixed gently to observe reaction. The result was graded as described by Quinn, et al. [19].

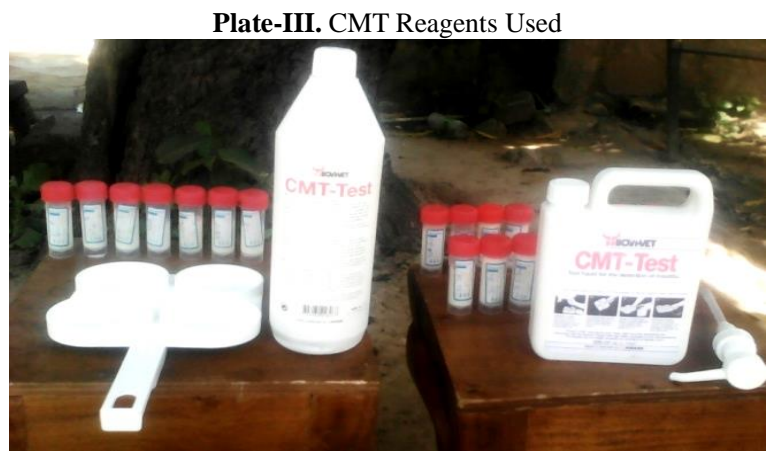

Plate-IV. Mixing of the CMT reagent and milk samples in the CMT Test Paddle

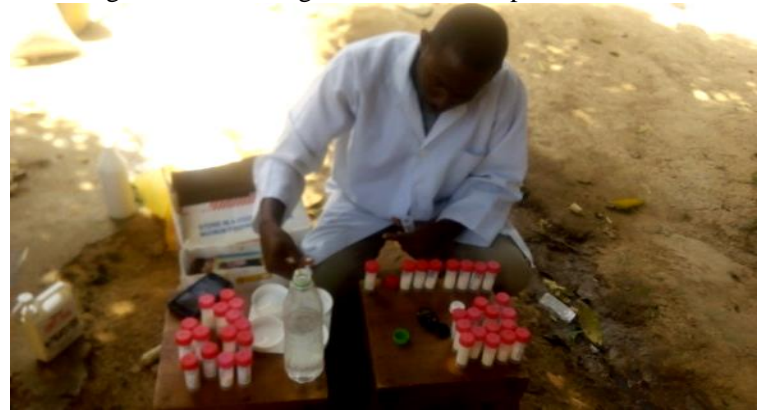

Plate-V. Swirling of CMT reagent and milk samples for the detection of Subclinical mastitis

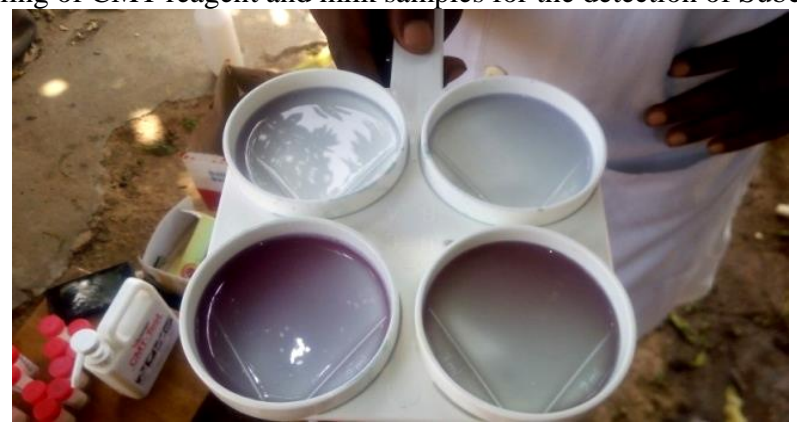

Plate-VI. Sample of CMT negative results without sign of coagulation or gel formation

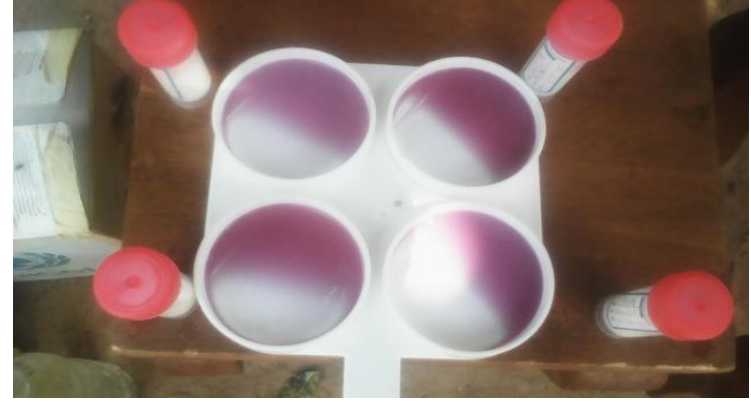

Plate-VII. Sample of CMT positive result showing coagulation or gel formation

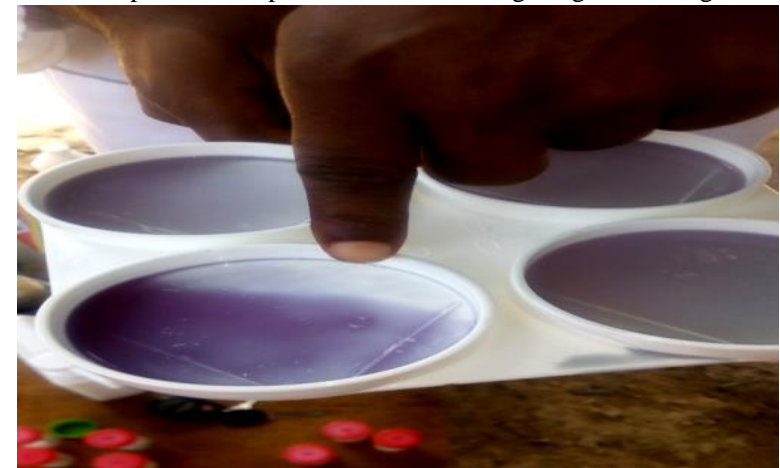


Plate-VIII. Manufacturer's Interpretative standard used

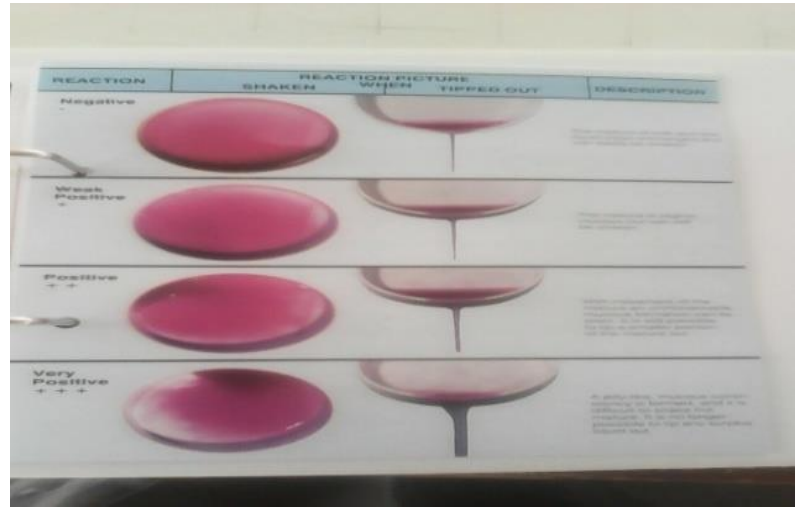

\section{Bacteriological Analysis of CMT Positive Milk Samples}

\subsection{Inoculation of Raw Milk Samples}

The CMT positive milk samples were inoculated on MacConkey agar (Oxoid, England) by streak method as described by Endale, et al. [18]. Briefly, a loop full of milk sample was streaked on the agar plates aseptically using quadrant method for each sample. The plates were incubated at $37^{\circ} \mathrm{C}$ and examined after 24 hours for growth.

\subsection{Primary Isolation of Coliform Bacteria}

To comply with the specific objectives of this study, bacteriological analysis was focused only on the identification and isolation of Coliform bacteria. Hence, pink to red distinct colonies resulting from the utilization of lactose on MacConkey agar were presumptively considered as Coliform bacteria. The suspected isolates were subcultured to get pure isolates. The pure isolates were cultured on Eosin Methylene Blue Agar (EMB) which is selective and differential for $E$. coli and other Coliform bacteria. Isolates that showed metallic green sheen on EMB were presumptively considered as $E$. coli, while those with coloured appearance were considered to be other Coliform bacteria. The suspected Coliform isolates were stored in Nutrient Agar slant for further characterization and identification using the conventional biochemical tests and Microgen A+B ID Kits (UK).

\subsection{Biochemical Characterization and Microgen Identification}

All suspected coliform bacterial isolates that stained red with Gram reaction were subjected to Conventional biochemical tests. The tests conducted were: Indole, Methyl Red, Voges-Proskauer and Citrate Utilization (IMViC) according to standard microbiological techniques described by Cheesborough [22] and Mbuk, et al. [12]. The suspected coliform bacterial isolates from the tests were identified up to species level using Microgen A+B Kit (UK) in accordance with the manufacturer's instructions.

\section{Results}

In this study, a total of one hundred and fourty seven (147) lactating bovines which comprised of bovines from thirty herds (30) across seven (7) herdsmen settlements within seven Local Government Areas of Kaduna State were examined for subclinical and clinical mastitis. Clinical examination of their udders revealed that none $(0.0 \%)$ of the studied bovine was positive for clinical mastitis.

Subclinical mastitis was detected by testing the raw milk samples from the bovines studied collected at cow level using California Mastitis Test (CMT) Reagent. CMT screening of the samples recorded prevalence of 19.7\% (Table 1). The higher prevalence of subclinical mastitis was recorded among bovines from settlements $\mathrm{G}$ and $\mathrm{A}$ in Birnin Gwari and Giwa Local Government Areas of Kaduna State respectively (Table 1), while the raw milk samples of bovines collected from settlements C and E in Chikun and Zaria Local Government Areas of Kaduna State had the lowest prevalence of $1(0.7 \%)$ each, and no coliform bacteria $(0.00 \%)$ was isolated in the samples collected from settlement D in Soba Local Government Area (Table 1).

Out of the 147 bovine milk samples screened for subclinical mastitis, $80.3 \%$ were negative, $7.5 \%$ were weakly positive, $12.3 \%$ were distinctively positive, and none was strongly positive (Table 2). The CMT weak positive and distinctive positive samples yielded $2.0 \%$ and $6.8 \%$ of Coliform bacteria respectively. However, the distinctively positive samples (++) had the highest number of Coliform bacterial isolates (Table 2). 
Table-1. Prevalence of subclinical mastitis and presence of Coliform bacteria among the bovines studied

\begin{tabular}{l|l|l|l|l|l}
\hline S/N & $\begin{array}{l}\text { Local Government Area// } \\
\text { Settlements/Herds }\end{array}$ & $\begin{array}{l}\text { No.of } \\
\text { Lactating } \\
\text { Bovines }\end{array}$ & $\begin{array}{l}\text { No.of } \\
\text { Bovines } \\
\text { Examined }\end{array}$ & $\begin{array}{l}\text { No.(\%) of samples } \\
\text { positive for } \\
\text { Subclinical astitis }\end{array}$ & $\begin{array}{l}\text { No.(\%) of samples } \\
\text { positive } \\
\text { coliform bacteria }\end{array}$ \\
\hline 1 & Giwa (Settlement A) & 50 & 24 & $6(4.1)$ & $2(1.4)$ \\
\hline 2 & Igabi (Settlement B) & 30 & 15 & $5(3.4)$ & $2(1.4)$ \\
\hline 3 & Chikun (Settlement C) & 39 & 19 & $3(2.0)$ & $1(0.7)$ \\
\hline 4 & Soba (Settlement D) & 27 & 12 & $1(0.6)$ & $0(0.0)$ \\
\hline 5 & Zaria (Settlement E) & 55 & 26 & $4(2.7)$ & $1(0.7)$ \\
\hline 6 & Sabongari (Settlement F) & 40 & 19 & $3(2.0)$ & $2(1.4)$ \\
\hline 7 & Birnin Gwari (Settlement G) & 68 & 32 & $7(4.8)$ & $4(2.7)$ \\
\hline & Total & $\mathbf{3 0 9}$ & $\mathbf{1 4 7}$ & $\mathbf{2 9 ( 1 9 . 7 3 \% )}$ & $\mathbf{1 2 ( 8 . 2 \% )}$ \\
\hline
\end{tabular}

Table-2. Prevalence of subclinical mastitis according to the degree of CMT reactions and associated coliform bacteria.

\begin{tabular}{l|l|l|l}
\hline S/N & Degree of CMT Reaction & Result of SCM Test & No. Positive of coliform bacteria \\
\hline 01. & Negative (-) & $118(80.3)$ & - \\
\hline 02. & Weak Positive (+) & $11(7.5)$ & $2(1.4)$ \\
\hline 03. & Distinctively positive (++) & $18(12.2)$ & $10(6.8)$ \\
\hline 04. & Strong Positive (+++) & $0(0.0)$ & - \\
\hline & Total & $\mathbf{1 4 7}(\mathbf{1 0 0 . 0 \%})$ & $\mathbf{1 2}(\mathbf{8 . 2 \%})$ \\
\hline
\end{tabular}

Key: CMT- California Mastitis Test; SCM- Subclinical Mastitis

In this study, the results of bacteriological, biochemical and Microgen identification of bovines raw milk samples revealed that settlements G in Birnin Gwari Local Government Areas of Kaduna State haboured the higher number $4(2.7 \%)$ of Coliform bacteria, while bovine's raw milk samples collected from settlements $\mathrm{C}$ and $\mathrm{E}$ in Chikun and Zaria Local Government Areas of Kaduna State haboured the highest number of 1(0.7\%) each, and no Coliform bacteria $(0.00 \%)$ was isolated in the samples collected from settlement D in Soba Local Government Area (Table 1). The results obtained in this study showed that out of the 29 CMT positive raw milk samples bacteriologically analyzed, overall prevalence of $8.2 \%$ of different species of Coliform bacteria was obtained: Klebsiella pneumoniae 7(4.8\%) and Escherichia coli 5(3.4\%). Klebsiella pneumoniae was the dominant species of Coliform bacteria isolated in this study (Table 3 and 4$)$.

Table-3. Result of Biochemical Characterization (IMVIC) of Isolates

\begin{tabular}{l|l|l|l|l|l}
\hline $\begin{array}{l}\text { Suspected } \\
\text { Coliform Isolates }\end{array}$ & $\begin{array}{l}\text { Indole } \\
\text { Test }\end{array}$ & $\begin{array}{l}\text { Methyl } \\
\text { Red Test }\end{array}$ & $\begin{array}{l}\text { Vogues } \\
\text { Proskauer } \\
\text { Test }\end{array}$ & $\begin{array}{l}\text { Citrate } \\
\text { Utilizatio } \\
\text { n Test }\end{array}$ & Probable organism \\
\hline C1 & + & + & - & - & Escherichia sp \\
\hline C2 & + & + & - & - & Escherichia sp \\
\hline C3 & + & + & - & - & Escherichia sp \\
\hline C4 & + & + & - & - & Escherichia sp \\
\hline C5 & + & + & - & - & Escherichia sp \\
\hline C6 & - & - & + & + & Klebsiella sp/Enterobacter sp \\
\hline C7 & - & - & + & + & Klebsiella sp/Enterobacter sp \\
\hline C8 & - & - & + & + & Klebsiella sp/Enterobacter sp \\
\hline C9 & - & - & + & + & Klebsiella sp/Enterobacter sp \\
\hline C10 & - & - & + & + & Klebsiella sp/Enterobacter sp \\
\hline C11 & - & - & + & + & Klebsiella sp/Enterobacter sp \\
\hline C12 & - & - & + & + & Klebsiella sp/Enterobacter sp \\
\hline Key: C 1-C5 = Probable Escherichia species; C6-C12 & & Probable Klebsiella/Enterobacter species
\end{tabular}

Table-4. Result of Microgen Tests for the Identification of the Isolates

\begin{tabular}{l|l|l|l}
\hline Presumptive Isolates & Octal Number & Final Identification & Percentage Probability \\
\hline EC1 & 04600570 & Escherichia coli inactive & $96.58 \%$ \\
\hline EC2 & 05604520 & Escherichia coli inactive & $90.24 \%$ \\
\hline EC3 & 04604420 & Escherichia coli inactive & $86.46 \%$ \\
\hline EC4 & 04405421 & Escherichia coli inactive & $88.26 \%$ \\
\hline EC5 & 07600570 & Escherichia coli & $49.76 \%$ \\
\hline KP1 & Klebsiella pneumonia & $99.71 \%$ \\
\hline KP2 & Klebsiella pneumonia & $95.07 \%$ \\
\hline KP3 & 47523666 & Klebsiella pneumonia & $95.2 \%$ \\
\hline KP4 & 47523777 & Klebsiella pneumonia & $99.3 \%$ \\
\hline KP5 & 47523757 & Klebsiella pneumonia & $87.34 \%$ \\
\hline KP7 & 47555777 & Klebsiella pneumonia & $65.13 \%$ \\
\hline KeyC1-EC5 & 47544776 & Klebsiella pneumonia & $57.67 \%$
\end{tabular}

Key: EC1-EC5 = Escherichia coli (5); KP1-KP7 = Klebsiella pneumoniae (7) 


\section{Discussion}

A total of 147 lactating bovines from thirty herds of cattle across seven herdsmen settlements in parts of Kaduna State, Nigeria were investigated in a cross sectional study conducted between October, 2017 and January, 2018. The search light of this study was primarily focused on Coliform bovine mastitis especially, the various environmental and managerial factors that can influence the prevalence of the disease among the studied population.

In this study, a prevalence of $19.7 \%$ has been established for subclinical mastitis at cow level. This is lower than 29.7\% reported in Kaduna State, Nigeria [12], 30.9\% in Plateau State, Nigeria [13], 85.33\% in Sokoto State, Nigeria [2], 64.1\% in Egypt [11], and 52.3\% in China [23]. However, it is higher than 10.5\% reported in Iran [24]. Differences in sample sizes, environmental conditions, poor hygienic level of rearing and milking the animals, and the type of management might be responsible for the discrepancies in the prevalence of subclinical mastitis obtained by various researchers.

The results of subclinical mastitis obtained in this study based on the degree of CMT reactions revealed that none of the screened samples was strongly positive $(+++)$. This might be responsible for the reason why no case of clinical mastitis was recorded as the number of the organisms might not have attained a threshold of causing clinical mastitis among the studied animals. This agrees with the findings that most cases of subclinical mastitis are of short duration during the lactation period due to the inhibitory activity of lactoferin [15]. Conversely, studies have also shown that some strains of Coliform bacteria possess certain virulence genes that confer on them the ability to survive in mammary gland in the face of host defense mechanism [25]. Therefore, the major reason for not recording any case of clinical mastitis could be largely due to the fact that herdsmen usually isolate and cull any of their bovines with visible signs of clinical mastitis.

This study established a prevalence of $8.2 \%$ for Coliform bacteria associated with bovine mastitis among the studied animals based on phenotypic identification. This closely agreed with the work of Mbuk, et al. [12] who reported a prevalence of $10.3 \%$ in Kaduna State, Nigeria. However, higher prevalence of $52 \%$ has been reported in Sokoto, Nigeria [26], 22.9\% in Kaduna State, Nigeria [27], 23.5\% in Gambia, Senegal and Guinea [28], 66\% in Tanzania [29] and 70\% in Madurai, India [30].

The species of coliforms isolated in this study were Klebsiella pneumoniae and Escherichia coli. Klebsiella pneumonia was the dominant species associated with bovine mastitis in this study. This is in agreement with the work of Mbuk, et al. [12] who isolated similar species of these organisms in Kaduna State, except for Escherichia coli. These findings also agreed with the report of Hogan and Smith [15] that said Klebsiella pneumoniae and Escherichia coli are the species of coliforms most frequently isolated from cases of bovine mastitis. The dominance of Klebsiella pneumoniae in this study also agreed with the report of Podder, et al. [31] that said Klebsiella pneumoniae is well adapted to survive in the udder and usually establishes subclinical mastitis infection of long duration which can be shed in milk, facilitating transmission to healthy animals mainly during milking process. Generally, the presence of these Coliform bacterial species in the milk is an indication of feacal and environmental contamination resulting from poor hygienic practices of rearing and milking the animals as they are no established mastitis control practices employed among the herdsmen.

Furthermore, from epidemiological point of view, the presence of these organisms in milk is of significant public health threat. This assertion is affirmed by the report of United States Public Health Services, Department of Health and Human Services that listed all species and serotypes of Klebsiella, all species of Proteus, Escherichia, Citrobacter, Enterobacter, Pantoae and Serratia as dangerous biological agents that have the potential to pose a severe threat to public health and safety, to human and animal health, or to animal and plant products [32]. Consequently, the Coliform species isolated in this study are part of this list. Therefore, consumption of raw milk from bovines infected with coliform mastitis poses a potential danger to the health of the consumers.

\section{Conclusion}

Based on the results obtained from this study, it is hereby concluded that the prevalence of Subclinical mastitis obtained was moderate in this region and found associated with coliform bacteria. Furthermore, Klebsiella pneumonia and Escherichia coli were the species of coliforms associated with bovine mastitis within the population studied. However, the presence of these organisms in the milk of pastoral herds reared for commercial purpose is an indication of feacal and environmental contamination which poses a potential threat to the consumers as they have been implicated in several human and animal diseases. Therefore, an improved hygienic process in the rearing and milking of the animals among pastoral herds in compliance with international standards is strongly recommended. Thus, there is a need for continuous enlightenment and urgent intervention of the Nigerian government and nongovernmental health related organizations in improving the living condition of the pastoralists, especially in the provision of potable water and establishment of standard ranching system.

\section{References}

[1] Lawal-Adebowale, 2014. "Dynamics of ruminant livestock in the context of the nigeria agricultural system."

[2] Shittu, A., Abdullahi, J., Jibril, A., A., M. A., and Fasino, F. O., 2012. "Subclinical mastitis and associated risk factors in lactating cows in the savannah region of nigeria." BMC Veterinary Research, vol. 28, p. 134.

[3] Sumathi, B. R., 2008. "Antibiogram profile based dendrogram analysis of Escherichia coli serotypes isolated from bovine mastitis." Vet. World, vol. 1, pp. 37-39. 
[4] Beheshti, R., Shayegh, J., Eshratkhah, B., and Ghiasi, G. J., 2010. "Prevalence and etiology of subclinical mastitis in ewes of the Tabriz region." Iranian Global Veterinar, vol. 4, pp. 237-241.

[5] Hussain, R., Javed, M. T., Khan, A., Mahmood, F., and Kausar, R., 2012. "Mastitis and associated histopathological consequences in the context of udder morphology." International Journal of Agricultural Biology, vol. 14, pp. 947-952.

[6] Radostis, O. M., Gay, C. C., Blood, D. C., and Hinchlif, K. W., 2000. Veterinary medicine: A textbook of the disease of cattle, sheep, pigs, goats and horses. 9th ed ed. ELBS and Baillier Tindall, pp. 563-660.

[7] Sharma, N., Singh, N. K., and Bhadwal, M. S., 2011. "Relationship of somatic cell count and mastitis, An overview." Asian-Australian Journal of Animal Science, vol. 24, pp. 429-438.

[8] Gera, S. and Guha, A., 2011. "Assessment of Acute phase proteins and nitric oxide as indicators of subclinical mastitis in Holstein Haryana cattle." Indian Journal of Animal Science, vol. 81, pp. 1029-1031.

[9] Sharma, N., 2007. "Alternative approach to control intramammary infection in dairy cows, A review." Asian Journal of Animal and Veterinary Advances, vol. 2, pp. 50-62.

[10] Halasa, T., Huijps, K., Osteras, O., and Hogeveen, H., 2007. "Economic effects of bovine mastitis and mastitis management. A Review." Veterinary Quarterly, vol. 29, pp. 18-31.

[11] Lamey, A. E., Ammar, A. M., Zaki, E. R., Khairy, N., Moshref, B. S., and Refai, M. K., 2013. "Virulence factors of escherichia coli isolated from recurrent cases of clinical and subclinical mastitis in buffaloes." International Journal of Microbiological Research, vol. 4, pp. 86-94.

[12] Mbuk, E. U., Kwaga, J. K. P., Bale, J. O. O., Boro, L. A., and Umoh, J. U., 2016. "Coliform organisms associated with milk of cows with mastitis and their sensitivity to commonly available antibiotics in Kaduna State, Nigeria." Journal of Veterinary Medicine and Animal Health, vol. 8, pp. 228-236.

[13] Suleiman, A. B., Umoh, V. J., Kwaga, J. K. P., and Shaibu, S. J., 2013. "Enterotoxigenicity and antibiotic resistance of staphylococcus aureus isolated from subclinical bovine mastitis milk in plateau state, Nigeria." Research Journal of Microbiology, vol. 8, pp. 101-107.

[14] Tiwari, A., Sisodia, R. S., Sharma, R. K., Misraulia, K. S., and Garg, U. K., 2000. "Incidence of subclinical mastitis in cows of Malwa Region of Madya Pradesh." Indian Journal of Dairy Science, vol. 53, pp. 328331.

[15] Hogan, J. and Smith, K. L., 2003. "Coliform mastitis." Veterinary Research, vol. 34, pp. 507-519.

[16] KDSG, 2008. "Kaduna State achievement in data on estimated annual animal population, fish production and investment opportunities in Kaduna State. Kaduna State Government." pp. 16-18.

[17] Ugwu, D. S., 2010. "Dairy Production among small and medium scale farmers in Nigeria: A case study of Kaduna and Kaduna States." Journal of Agricultural Sciences, vol. 6, pp. 01-06.

[18] Endale, M., Eyob, Eshetu, Addisu, Awekew, and Noad, T., 2016. "A study on the prevalence of Bovine Mastitis and associated risk factors in and the surrounding areas of Sodo Town,Wolaita Zone, Ethiopia." Global Journal Incorporated, vol. 6, pp. 2249-4626.

[19] Quinn, P. J., Markey, B. K., Carter, M. E., Donnelly, W. J. C., Leonard, F. C., and Maghir, D., 2002. Veterinary microbiology and microbial disease. London: Blackwell Science Ltd. pp. 191-208.

[20] Radostis, O. M., Gay, C. C., Blood, D. C., and Hinchlif, K. W., 2007. Mastitis in veterinary medicine. 9th ed ed. London: Harcourt Ltd. pp. 174-758.

[21] Middleton, J. R., Saeman, A., and Fox, L. K., 2014. "The national mastitis council, A global organization for mastitis council and milk quality, 50 years and beyond." Journal of Mammary Gland Biology and Neoplasia, vol. 19, pp. 241-251.

[22] Cheesborough, M., 2009. District laboratory practice in tropical countries vol. 2. UK: Cambridge University. pp. 65-67.

[23] Memon, J., Kashif, J., Yaqoob, M., Kiping, W., Yang, Y., and Hongjie, F. C., 2013. "Molecular characterization and antimicrobial sensitivity of pathogens from subclinical mastitis in Eastern China." Pakistan Veterinary Journal, vol. 33, pp. 170-174.

[24] Momtaz, H., 2010. "Investigation of virulence factors in Escherichia coli isolated from clinical and subclinical mastitis." Bulgarian Journal of Medicine, vol. 13, pp. 122-126.

[25] Lehtolainen, T., Pohjanvirta, T., Pyorala, S., and Pelkonen, S., 2003. "Association between virulence factors and clinical course of Escherichia coli mastitis." Acta Veterinaria Scandinavica, vol. 44, pp. 203205.

[26] Junaidu, A. U., Salihu, M. D., Tambuwala, F. M., Magaji, A. A., and Jaafaru, S., 2011. "Prevalence of mastitis in lactating cows in some of selected commercial dairy farms in Sokoto Metropolis." Pelagia Advanced Applied Science Research, vol. 2, pp. 290-294.

[27] Agunbiade, T. B., Umoh, V. J., Whong, C. M. Z., and Ella, E. E., 2015. "Assessment of bovine milk obtained from selected farms in zaria environs for toxigenic strains of escherichia coli." Academic Journal of Life Sciences, vol. 1, pp. 8-13.

[28] Hempen, M., Unger, F., Muntermann, S., Seck, M. T., and Niamy, V., 2004. "The hygienic status of raw and sour milk from smallholder dairy farm and local market and potential risk for public health" in The Gambia, Senegal and Guinea. Animal Health Research Working Paper 3. ITC (International Trypanotolerance Centre), Banjul, the Gambia." p. 54.

[29] Karimuribo, E. D., Kusiluka, L. J., Mdegela, R. H., Kapaja, A. M., Sindato, C., and Kambarage, D. M., 2005. Tanzania Journal of Veterinary Science, vol. 6, pp. 213-221. 
[30] Lingathurai, S. and Vellathurai, P., 2010. "Bacteriological quality and safety of raw cow milk in Madurai". South India." Available: http://www.webmedcentral.com/article_view/1029

[31] Podder, M. P., Rogers, L., Daley, P. K., Keefe, G. P., Whitney, H. G., and Tahlan, K., 2014. "Klebsiella species associated with bovine mastitis in Newfoundland." PLOS ONE, vol. 9, p. 106518.

[32] Bynum, J., 2011. "Coliforms, Dangerous biological bioterrorism agents." The Watchers, pp. 1-81. 